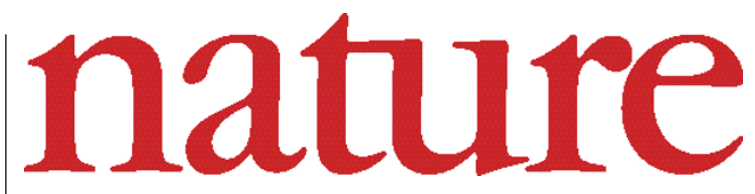

12 December 2002 Volume 420 Issue no 6916

\title{
Prioritizing Australia
}

Australia's researchers have been set national goals by their government. The underlying agenda is to ensure that the country's institutions spend scarce funds more wisely and in a way that reflects joined-up thinking.

$\mathrm{n}$ a landmass nearly the size of the United States and occupied by fewer than 20 million inhabitants, Australia's research community suffers not so much from a tyranny of distance as one of scale. Australian science takes pride in wringing high-quality research from scant resources. Despite increases in government funding over the past two years, industrial support for research remains scarce, and Australia's universities are cash-strapped. Now it risks slipping further behind as the price of research rises and the United States and Britain bolster research funding to levels that dwarf Australian investment.

With its tight resource constraints, Australia must target areas of strength or greatest need. Last week the federal government announced priorities for research in science and technology (see page 597), and adopted broad themes couched with politically palatable rhetoric. The theme 'Safeguarding Australia' will resonate with a nation burying its dead from the terrorist attack in Bali and worrying about bioterrorism and susceptibility to agricultural epidemics, such as foot-and-mouth disease. Likewise, an 'Environmentally Sustainable Australia' will be balm to a country ravaged by drought, salinity and bushfires.

With the two other themes embracing health and technology, it seems that relatively few areas of scientific pursuit will miss out, especially after some expedient re-labelling of research objectives. Notable exceptions are big physics and astronomy, although enterprising efforts in instrumentation by Australian astronomers could, and should, be considered a new technology frontier.

This priority setting is a politically strategic exercise to encourage the various parts of the research sector to work more closely together using existing funds. The government's light-touch approach to nudging its research objectives may bring a sigh of relief from researchers, but the devil may be in the implementation. No apportionment of existing funds to the priorities has been specified.
Demonstrable success in priority areas will no doubt be perceived as a draw card for future funding. In this climate, research agencies must be careful not to pirate a broad basic-research base in response to the prioritization demands of their paymaster.

A measurable return on investment will be expected, and Australian researchers are not alone in trying to devise sound performance indicators for fundamental research. Traditional measures of output, such as publication record, need to be carefully handled: dependence on them as a criterion for funding is stimulating an overproduction of Australian publications (see Nature 419, 877; 2002).

Furthermore, there have been expectations that industry would blossom around research investment. But venture capital and pharmaceutical investment remain weak, despite government-supported seed funds and tax incentives. The question remains whether there is a strong entrepreneurial attitude in Australia towards commercializing discoveries, and whether overseas investors can be tempted away from more familiar territories. This remains a key challenge for government, business and entrepreneurial researchers.

The priority setting is intended not only to focus the minds of researchers on problems relevant to the populace, but to encourage nationally coordinated networks of research to attain the critical mass needed to produce top-quality science. This is supported by the government's call last month for a national audit of the research sector, due for completion next year. In theory, this could help to meld the fragmented research community, and mobilize funds and efforts across research 'silos' to address common objectives. But these collaborations must be productive, rather than mere marriages of convenience to attract more funding. To that end, Australia must address the challenge of how best to foster collaboration without diminishing the competitive and independent spirit that drives its best, world-class research.

\section{Through the protein labyrinth}

\section{Proteomics is delivering results that pose new problems in data management and compatibility.}

$\mathrm{S}$ pots, bands and peaks. Readers could be forgiven for being hard pressed to make a connection but, to the up-and-coming biologist, resolving spots and bands on polyacrylamide gels and reading peaks from a mass spectrophotometer lie at the heart of high-throughput biology. Technology and robotics lead the proteinbiology revolution and, as quantity gains credence, biologists must take control of the avalanche of information being presented.

Proteomics is defined as the identification and quantitative expression analysis of every protein encoded by a genome, characterizing protein-protein interactions and assigning these protein complexes with function. Biologists have undertaken large-scale screens to identify every protein expressed on a single chromosome and determine the complement of proteins that defines a complete biological process. But in the rush, the golden rules of biology that allow for easy comparison, exchange and verification of data are being overlooked.

Hordes of data have been analysed, but it is difficult to compare data sets because they are derived under different conditions, presented in different formats and benchmarked against different reference sets. This information must be accommodated in 'interoperable' repositories, and many databases are being set up for this purpose. This requires distributed databases from the outset that include common machinereadable tags for the species, strain or tissue used, say. By agreeing a minimal set of common standards, the proteomics community will ensure that their many databases can communicate with each other in the same language, and be queried as if they were a single resource.

In April this year, the Human Proteome Organisation founded the Proteomics Standards Initiative (http://psidev.sourceforge.net), which aims to define the standards required. This will be a huge challenge, not least because, as one computer scientist once quipped, "standards are so important that everyone wants their own". But if the full promise of proteomics is to be realized, the community and the bioinformaticians that service it need to pay more attention to the often thankless task of standard setting. Only then will it be possible to find order in the labyrinth of biomolecular networks. 